bibliography of 686 references and the very useful index appended to each volume. The ophthalmic world is deeply in Dr. Berliner's debt, and no ophthalmological library will be complete without this volume.

In the production as a whole the publisher must also receive much credit. The book is luxuriously produced, well printed, and the multitude of illustrations are outstanding in their artistry and clarity.

\title{
OBITUARIES
}

\section{REGINALD ERNEST BICKERTON, D.S.O., T.D., M.B., Ch.B.}

R. E. BICKERTON, whose death at the age of 79 was recently announced, had been for 42 years Ophthalmic Surgeon to the Dreadnought Seamen's Hospital, Greenwich, and was Consulting Ophthalmic Surgeon to the Evelina Hospital for Sick Children, and to the Royal Waterloo Hospital for Women and Children. He did valuable work for St. Dunstan's and was chairman and visiting Ophthalmic Surgeon to the Royal School for the Blind, Leatherhead. He was Hon. Surgeon to the King, 1927-32.

In the 1914-18 war he performed distinguished service as an ophthalmic surgeon mainly in the Mediterranean theatre, being twice mentioned in despatches and winning the D.S.O.

Bickerton was loved and respected by all who knew him. $\mathrm{He}$ had a remarkable presence, urbane, kindly, and always completely unruffled however trying the circumstances. He approached ophthalmic problems in a leisurely and contemplative fashion, never forgetting the personality of his patients. He would start his outpatients at the Dreadnought in the late afternoon, and the work would go steadily on until past midnight. It was in vain that officious residents endeavoured to clear away some of the old patients. They simply refused to budge until they had seen the Great Man. Bickerton had an unrivalled memory for 'names and faces; and as each patient entered, would greet him as a friend, asking in detail about various members of the family who had been seen at previous visits. The writer well remembers how the Greenwich patients would bring their children and discuss what careers they should take up, receiving shrewd advice from the ophthalmic surgeon. When eventually the discussion came round to ophthalmic matters, Bickerton's advice was always practical, concise and sound, well worth the long wait for the patient.

In ophthalmology, Bickertons's interests leaned to the medical side; but his cataract and glaucoma operations were pretty to watch and very successful.

He will be greatly missed for his kindly personality and his fund of inimitable anecdotes.

L.H.S. 